\title{
Generic Shifts in Women's Travel Writing between Late Nineteenth and Early Twentieth Century Bengal
}

\author{
Shrutakirti Dutta \\ PhD Scholar, Department of English, Jadavpur University, West Bengal, India. Orcid: oooo- \\ ooo2-6781-9307. Email: shrutakirtidutta.93@gmail.com
}

\begin{abstract}
Women's travel writing in Bengal proliferated in the late nineteenth and early twentieth century through the popular form of serialized publications in journals such as Bharati (1877), Dasi (1892), Prabasi (1901), among others. However, to perceive this rich output of travel literature as a single, homogenous genre would be fallacious. Travel writing in this time undergoes several generic modifications as it journeys through the turn of the century. Through my paper I would like to trace these shifts within Bengali women's travel narrative using the stretch of aryavarta as the anchoring landscape. From Prasannamae Debi in 1888 to Nanibala Ghosh in 1933, these travellers from Bengal travel to the north and north-west regions of India, mapping the same landscape but within diverse narrative frameworks, and in so doing, dramatically (and one could argue deliberately) alter the land they wish to represent. Their subjective position as women writers further inform and complicate their work, as do the contemporary political framework of the time they respectively inhabit. What the reader is left with can conservatively be termed travel writing, but can equally and with ease inhabit the roles of memoir, political writing, ethnographical study, among others.
\end{abstract}

Keywords: Travel Writing, Colonial Bengal, Women's History, Hindu Revivalism, Aryavarta

The year 1869 remains a watershed moment in the history of travel, with the opening of the Suez Canal and ready access to voyage via steamer ships. In Bengal we find sporadic and passing accounts of travel from before this time. One of the earliest instances can be seen in a collection of letters from Dwarkanath Tagore to his son Debendranath Tagore describing his experiences on his second visit to Europe, which was published in a short lived periodical Bidyadarshan in 1842. Around 1855 Ishwar Chandra Gupta's periodical Sangbad Prabhakar published Bhramankari Bandhur Patra-an epistolary account of travel across various parts of eastern India undertaken by Ishwar Chandra Gupta himself, but fashioned as anonymous letters written to the editor of the periodical, Shyamacharan Bandhopadhyay. However, a greater frequency of travel did not necessarily correlate with a proliferation in travel writing in Bengal.

In Bengali literary traditions, travel was not deemed the most popular activity, especially among orthodox Brahmins who feared that travelling outside the ambit of sacred Hindu geography would lead to moral and spiritual contamination. Simonti Sen traces the origins of the word bhraman (travel), which stems from the Sanskrit root bhram, which means to make a mistake or be mistaken. Unlike in the western literary canon where travel or quests were valourised, as in Homer's Odyssey, the Hindu shastric tradition leaned in favour of sedentary lifestyles (Sen, 2005), with travel being undertaken either for religious purposes, or for trade. In 1858, Tarinicharan Chattopadhyay's Bharatbarser Itihas, which was a seminal text of history at the time, outlines the contemporary perception of travel thus:

(c) AesthetixMS 2020. This Open Access article is published under a Creative Commons Attribution Non-Commercial 4.o International License (http://creativecommons.org/licenses/by-nc/4.o/), which permits non-commercial re-use, distribution, and reproduction in any medium, provided the original work is properly cited. For citation use the DOI. For commercial re-use, please contact editor@rupkatha.com. 
In earlier times, foreign travellers in India marvelled at the courage, truthfulness and modesty of the people of the Aryan clan; now they remark mainly on the absence of those qualities. In those days Hindus would set out on conquests and hoist their flags in Tatar, China and other countries; now a few soldiers from a tiny island far away are lording it over the land of India. [...] Then the Hindus would sail to Sumatra and other islands [...] Now the thought of a sea voyage strikes terror in the heart of a Hindu, and if anyone manages to go, he is immediately ostracized from society.(Chattopadhyay, 1878, p. 32)

Travel writing as a genre only becomes popular in the $1870 \mathrm{os}$ and $1880 \mathrm{os}$, and this can be attributed to an amalgamation of several factors - the advent of print capitalism and easy access to printing presses, the proliferation of periodicals such as Prabasi, Bharati, Bangadarshan, Kalpataru, Nabyabharat that made space for the publication of serialised travelogues or bhramankahini, and the emergent perception of travel writing as a means of modern self-expression. Bhaskar Mukhopadhyay, in his essay "Writing Home Writing Travel" (2002) surmises that this development owes credit to a larger symptom taking shape in Bengal at the time-that of the rise of vernacular prose, and with it the impulse to forge a cohesive national identity. Along with the emergence of the novel, biography, autobiography and diary, travel writing as a genre comes to the fore as another tool to fashion a modern Bengali self.

Much of the travel writing which did emerge and prove popular at this time were those authored by Hindu, upper class, western educated males, who were often renowned luminaries, scholars, or litterateurs in their own right. Several of the travel accounts are of men travelling outside India, usually to England. These works contained observations on western culture and a comparative study with India's own. Romesh Chunder Dutt wrote Three Years in Europe: 18681871, which was published in 1896. Both Rabindranath Tagore and Vivekananda authored various works on travel. An earlier account of travel writing was Bholanauth Chunder's Travels of a Hindoo (1869) which chronicled his journey from Bengal to Punjab.

\section{I}

Socially sanctioned forms of travel for women till the mid nineteenth century was largely restricted to pilgrimage(Chatterjee, 1995, p. 385). However, with the advent of the railways and the opening of the Suez Canal, by the mid-nineteenth century we have instances of women, usually from educated Bengali upper-class families, travelling for entirely secular reasons-for convalescence, their husbands' work, for leisure, or even for education. Aru Dutt and Toru Dutt went to England at around 1870 to pursue an education (Mukhopadhyay, 2018, p. 14). In 1871 Rajkumari Bandhopadhyay, wife of social worker Shashipada Bandopadhyay, became the first Indian woman to visit England (Shekhar, 2017). In 1877 Jnadanandini Debi, along with her children, travelled by ship to England to accompany her husband for his work. In each of these instances, the act of travelling to a foreign land was deemed sacrilegious and transgressive, with the women facing extreme social backlash and, in the case of Rajkumari Bandhopadhyay, ostracisation. However, these acts set the way for further instances of travel, and more importantly, written accounts for the same. Krishnabhabini Das travels to England in 1882, and writes England e Bangamahila in 1885. In 1894 Jagatmohini Debi sets sail for England, and in 1902 publishes England e Saat Mash.

Before being compiled as books, these travel writings were often published serially in periodicals like Tattwabodhini (1843), Dasi (1892), Prabasi (1901), lending themselves well to the epistolary form. Thus, several of these works mimic the structure of personal letters and often 
appear conversational in tone. Swarnakumari Debi's "Darjeeling Patra" published serially in Bharati in 1886 is a fine example of this.

Several tropes emerge in travel writing by women at this time. The more recreational aspects of travel are often undercut by descriptions of practical inconvenience faced by the traveller. Perhaps this is done deliberately to temper the frivolity associated with travelling for leisure, as opposed to travel undertaken as part of a pilgrimage or for trade. There certainly appears a break in the narrative mode between early nineteenth and mid nineteenth century travel writing by women. Kumkum Chatterjee (1995) posits, this is to demarcate this type of literature as separate from the religiously coloured travel writing emerging from pilgrimage. She traces a departure from earlier modes of travel around the mid nineteenth century. Comparing two accounts of pilgrimages, in 1770 and 1857 , she observes that while the former account is pivoted around the moral or religious impulse, the latter is concerned with "bharatdarshan"(Chatterjee, 1995, p. 385-86). We will return to this trope in Prasannamae's Aryabarta (1885) and discuss the larger political context behind its emergence.

Another generic trope adopted by female writers of travel include extensive apologia as precursor to the text, or in certain cases, used as a refrain throughout the body of work. In the 1933 preface to Aryabarta, Nanibala Ghosh takes care to mention her complete disinterest in authoring a work of travel. It is clearly important for Ghosh to situate the impulse to write and document what she sees as something extraneous to her own will and whim. The solo woman traveller is also quick to draw the reader's attention to familial connection framing her travel. Girindranandini Debi dedicates Dholpur (1897) to her father from which the reader can infer that it is her husband's work that takes her to Dholpur. Prasannamae Debi dedicates Aryabarta to her daughter, Priyambada.

The negotiation with oneself (and the reader) to justify the need to travel is prevalent in varying degrees in the works of the women writers discussed in this paper. This could be symptomatic of women's writing in nineteenth century Bengal in general, where discomfort with authorship and autonomy had to be performed. Rassundari Dasi's Amar Jiban (1876) is an example of the trope of apologia, where the author is constantly aware of the transgressive act of writing and reading. Another recurrent trope in these works of travel is the mention of works by other authors, and the female authors' familiarity with the same. Prasannamae Debi alludes to Bholanauth Chunder's Travels, even suggesting amendments to his text. She expresses familiarity with Bankimchandra's works, quotes Shelley's poems, and engages with articles published in The Statesman. Swarnakumari Debi quotes lines from Browning's poetry, and mentions Tennyson. She ensures the reader knows about the ubiquitous presence of western literature in her life, as she describes a regular evening at her house where everyone gathers around to read excerpts from Victorian poets. These instances perhaps betray a certain anxiety in the authors to prove their scholarship and worldliness to their readership.

These generic and gendered tropes aside, the travel writers from Bengal discussed in this paper have one other similarity: the women travel to the north and north-west part of India, traversing the stretch known as the 'aryavarta,' at different points in time. However, despite having the same anchoring landscape, this is where their similarity ends. The writers' engagement with their landscape, the form and content of their travel text, and the affect of their writing are vastly different from each other. This paper argues that one can see several generic modifications within the ambit of travel writing in under fifty years (1885-1933). In these women's travel writing (Prasannamae Debi's Aryabarta, 1885; Nanibala Ghosh's Aryabarta,1933), we find that landscape and its affect are largely influenced by their representation which, within the context of late 
nineteenth century Bengal, is motivated and subsequently problematized by the confluence of colonialism and the Bengali women writers' unique subjective position.

\section{II}

Damayanti Dasgupta in her edited anthology of early Bengali women's travel narratives (2017) informs us that written under the pen name Niharika, Prasannamae Debi's Aryabarta was first published serially in 1885 as Aryabarte Bangamahila in the periodicals Alochona, and later Nabyabharat. It chronicled Prasannamae Debi's journey across various parts of Uttar Pradesh and Delhi. In 1888 it was compiled and reprinted as a book, and titled Aryabarta: Janaika Bangamahilar Bhraman Brittanta. This became one of the earliest books on travel written by a Bengali woman. The book is divided into two sections. The first chronicles her journey through parts of Uttar Pradesh and Delhi. The second is about her journey through Bihar. The chapters within these sections are named after the places visited or departed from (Etowa, Vrindavan), or in some instances, the site or artefact seen (Louhodwar or Iron gates, Hamam).

The beginning of Aryabarta is marked by a letter to Prasannamae Debi's daughter, Srimati Priyambadadebi, which summarises the recurring subjects of her travelogue-Indian history and Aryan supremacy. The letter reads like an exhortation to her readers to acknowledge and revel in the singular greatness of India. In a thinly veiled diatribe directed towards colonial rule, she implores her daughter to question the cause behind the nation's deterioration under the British empire. While lamenting the moral and spiritual decrepitude of the nation that has been brought about under colonial rule, she lists women from the Ramayana and the Mahabharata, as well as figures from Indian history, to act as foil and be perceived as role models, alluding to them under the blanket term 'Arya-nari' or Aryan women. She develops a narrative of heroism surrounding Aryan men and women from the very beginning, and this tone carries through the rest of the text as well. The letter is an emotionally charged piece through which Prasannamae Debi makes her views on her contemporary political climate known.

In "Aspects of Contemporary Hindutva Theology" Tanika Sarkar writes about the rise in satire towards British colonisers that begin to feature in literature and popular culture in Bengal by the 1880's, along with critique of colonial economic policies and a general lack of faith in the British administration (Sarkar, 2001, p. 140). Both reformist and revivalist forms of colonial criticism begin to co-exist, with the former targeting fiscal and administrative decisions taken by the government, and the latter resisting criticism of and alterations made to orthodox tenets and power hierarchies within Hindu theology. Subsequently, we begin to observe the image of the bharatmata or bangamata taking shape. In Anandamath we see the imagery of the mothergoddess or bharatmata, who embodies the nation. This icon is later aggressively popularised within the Hindu nationalist movement in the early twentieth century. Prior to this, the first known instance of the iconography comes as early as 1866 in a satirical piece titled Unabimsa Purana by Bhudeb Mukhopadhyay, first published anonymously in 1866 (Jha, 2017). In this, bharatmata is identified as Adhi-Bharati, the widow of Arya Swami, the embodiment of all that is essentially Aryan. A more popular instance of the icon of bharatmata in literature is seen in the play Bharat Mata by Bengali nationalist Kiran Chandra Bandyopadhyay which was first performed in 1873 (Jha, 2017) and embodied the image of a dispossessed motherland. Bankimchandra writes VandeMataram in Sanskrit as part of Anandamath, published in 1882, with Tagore later composing its music. The song is first sung within a political context at the 1896 session of the Indian National Congress (Wayback Machine, 2013). In 1897 Swami Vivekananda delivers a lecture 
on "The Common Bases of Hinduism" which references to the "holy Aryavarta... the land which, after all its sufferings, has not yet entirely lost its glory and its strength." (Wikisource, 2013)

The idea of an Aryan heartland becomes significant by the mid-nineteenth century, because it provides within its space a cohesive sense of community, a common history, racial legitimacy, and the assurance of a robust, pre-colonial past. Within the Hindu revivalist agenda, Aryavarta offers a homogenous, Brahmanical, geographically verifiable space with which to anchor the idea of a nation. It is not as if any sense of a desh or a country did not exist prior to this, but it is only at this time that it becomes politically significant to historicise the past and create a homogenous narrative for an otherwise pluralistic nation.

The nation of Prasannamae Debi's imagination is evidently uniformly Hindu, filled with references to Hindu mythology and consistently analysed against the backdrop of sites that are sacred within the Smriti texts. She frequently quantifies the value or splendour of the topography around her with respect to its connection with incidents within Hindu sacred texts. Although the travelogue focuses on the past, there runs a strain of anxiety running through the text of this past coming under threat of delegitimisation. Indeed, this anxiety is one that is shared by Prasannamae Debi's contemporaries who are looking at history for affirmation of self-reliance and "bhoot bharater gourab kahini" or "India's past glories". Evidence and substantiation appear to be the common refrain in both Banglar Itihash and Aryabarta when addressing the discourse surrounding Indian history, whether to disprove an unflattering representation of the nation or to stake a claim to a prosperous one. This can be seen as an influence of western modes of scholarship, one that set the precedence of privileging empirical evidence over indigenous knowledge systems. Unlike pre-colonial modes of history-writing where events and misfortunes appear pre-ordained, such as in Mrityunjay Bidyalankar's Rajabali (1808) which was the first printed text of Indian history in Bengali and an example of Puranic History (Chatterjee, 1993, pp. 77-81). By the mid-nineteenth century ideas of legitimacy that is situated within a nexus of verifiable facts become imperative to lend credence to any claim. It is for this reason that the need to provide irrefutable proof of greatness (and not merely assert that the past was great) becomes a fixation in Prasannamae Debi's text.

To achieve this, she deliberately creates a framework of longing and desire around images and knowledge of India's past. In so doing, she not only continues to draw attention to the larger symptom of India's alienation from its own history (by underlining a literal lack of access to the significant geographical sites), she also negates potential debates and doubt about the actual existence of this illustrious past. The fact that it existed is never in contention within the universe of Prasannamae Debi's text. As she travels from Agra to Indraprastha to Delhi, each evidence of decline and ruin becomes proof positive that there existed something better before this. Further, by situating her claim to this better past within the scope of a travelogue, and thus capitalising on the informally scientific, non-fictional nature of the genre, she manages to imbue the idea of this past with a degree of certitude. In sharp contrast with the characteristic pragmatism of the genre she works within, Prasannamae Debi chooses to use myth and religion as a recurring anchor for her text. She invokes religion to make sense of her landscape, making use of her knowledge of Hindu sacred texts to map or pivot her immediate geographical location, and sharing anecdotes along the way.

Although Prasannamae Debi's impulse to provide evidence is influenced by contemporary attitudes to modern scholarship, her mode to secure this evidence necessitates that boundaries of myth, lore, and facts overlap and become indistinguishable within the narrative of her text, not unlike Bidyalankar's Rajabali. While Prasannamae Debi is cognizant of cause and effect (her 
astute observation of political double standards in "Durgo" proves this), and subscribes to the western tradition of history writing, nevertheless, she deliberately allows certain elements of Puranic historic tradition to inform her narrative. Much like in Rajabali where myth and contemporary events seamlessly coexist, Prasannamae Debi too allows her description of landscape to run parallel to events in Hindu epics like the Ramayana and Mahabharata.

Prasannmae Debi finds India's deliverance in its history (Prasannamae, 2017/1885, p. 369). Using the metaphor of wind, she asserts that disseminating knowledge about the nation's past glories is the only way to inspire new agency and life among the people of India. This echoes the same sentiment that was the foundation behind Bankim's indignant claim "India has no history"(Bankim, 1999/1874, p. 289), and the one Ramananda will later repeat in Aitihashik tirthajatra. If we are to apply the antiquity-dark ages-renaissance approach (and indeed the consistent call for a "punarabishkar or "rediscovery" in these texts does support this analogy), then in order to have a renaissance or a re-birth there has to be unmistakable knowledge of a birth to begin with. To this end, Prasannamae Debi proceeds to create a repository of past deeds through her account of travel in Aryabarta, using memory as a trope in her writing. In so doing, Aryabarta's centre begins to shift from travel, to include history and politics in its scope. One could argue that travel is Prasannamae Debi's excuse to create a text of Indian history, one whose credibility remains unquestioned because it tethers its assertions to tangible, spatially verifiable structures.

\section{III}

Moving away from the nationalistic impulse that imbued the writings of Prasannamae Debi, we focus now on another strain of travel writing emerging out of colonial Bengal, one that has at its core the scientific impetus to classify and disburse knowledge. Simon Schaffer in his essay "Scientific Discoveries and the End of Natural Philosophy"(1986) notes the paradigm shift that occurs in the West in the late eighteenth century that marks the transition from classical research to mature scientific programmes. This shift extends to the secondary sciences as well and we begin to see the formalisation of earlier, informal knowledge systems (Bayly, 1999), with a growing interest in surveys, cartography, geographical explorations, and ethnographic interests. Within the Indian context, it becomes crucial for colonizers to have a firmer understanding of the territory they are now in charge of ruling, and thus the Survey of India is set up in 1767 to consolidate the territories of British East India Company. By the mid-19th century, British civil servants begin to combine imperialism with modern science, and embark on ethnographic surveys of the people of India. It is within this intersection of science and exploration that I situate the generic modifications of travel writing among the 19th Century Bengali literati.

Marking a strong departure from Prasannamae Debi's polemical writing in Aryabarta (Prasannamae, 2017/1885, p. 369) is Subarnaprabha Basu. In 1885 she writes a short essay "Taj Mahal" which is published in the periodical Sakha in 1886. While both women publish their writing around the same time, and talk about the same architectural structure (Prasannamae, p. 338; Basu, p. 103) their representation of the structure produces vastly different results. In case of Prasannamae Debi, the reader is taken through her reflections on mortality, her reservations about lives of excess, her musings on love - all of which arises from her encounter with the Taj Mahal. Her prose is dense, formal, and given to ornamental flourishes. The reader is not provided any historical data about the structure, nor facts about its construction. 
In sharp contrast, Subarnaprabha Debi's essay which is about the same length as the earlier text, reads less like travel writing and more like an encyclopaedic entry about the Taj Mahal. She provides detailed data about the monument and the area around it, the logistics behind its construction, and includes its distance from Bengal along with the measure of time taken to travel via railway. At a glance one can see the keen mathematical precision with which she chooses to visually map her text. There is little room for subjectivity within her work. This proclivity to substantiate the written word with irrefutable data betrays a scientific bent of mind. Indeed, Subarnaprabha Debi's history corroborates this assumption. She was the sister of scientist Jagadish Chandra Bose, and her son was the physicist Debendramohan Basu. She studied at Bethune School and later became editor of Bangamahila Samaj (Dasgupta, 2016, p. 209). She also wrote sporadically for the children's' periodical Sakha (later Sakha O Sathi).

About a decade later in 1897,Girindranandini Debi publishes Dholpur (Rajput Jaati-r Samaj Chitra) through one Surendramohan Borai .The text is entirely descriptive in nature, giving us accounts of the culture, climate, rites and rituals, attire, food habits, customs, diseases, and the people of Dholpur. There is little to no analysis of the material Girindranandini Debi gathers, and her rare personal comments, if any, usually comes in the form of criticism of cultural practices that she is unfamiliar with or finds superfluous. She places Hindi terms within quotes and usually provides an explanation or translation in the line itself. There is no separate gloss provided. The text is divided into five chapters, with further subdivisions in each. These subdivisions are arbitrary and follow no consistent theme. However, the primary focus of Dholpur is on matters of religious significance, especially pujas, as well as rituals surrounding marriage, pregnancy, childbirth and childrearing, and finally, practical matters of housekeeping. The text may well be treated as an encyclopaedia of rituals and customs of Dholpur. As in Subarnaprabha's text, here too the first chapter begins by mapping the exact location and geographical boundary of Dholpur.

While the output of this text can't be termed "scientific" in the canonical sense, it certainly is a detail driven work that exemplifies the colonial proclivity for collection and classification of data. The proto-ethnographic impulse of the text comes through in Girindranandini's encyclopaedic entries about items used in religious ceremonies, detailed notes on the attire and ornaments of men and women, the description of their physiognomy. It must be noted that Girindranadini Debi's form of travel writing, which uses an ethnographer's position and contemporary western ethnographical practices, allows her to turn her gaze back onto the "natives", aligning herself closer to the coloniser than the (doubly) colonised. While this impulse can be partially attributed to a change in the manner in which the Bengal literati began to perceive themselves vis-a-vis the "others" in their own land, it is also a result of internalizing and affecting certain styles of writing with a specific audience in mind. While Girindranandini does not explicitly adopt the tone of "the marvelous" (Nayar, 2005) within her narrative, nevertheless she consistently maintains a degree of distance and alienation from the subjects of her writing, adopting a narrative of distance in order to lend credence to her ethnographic effort.

The politics of such a representation aside, both Girindranandini Debi and Subarnaprabha Debi illustrate through their travel writing the early strains of an intuitive (or acquired) understanding of collecting, classifying and disseminating data about the "people of Hindustan," allowing their travel texts to intersect both literature and field sciences. 
Moving almost half a century forward, to the year 1933, we observe a firmer place for ethnographic interest within the space of travel writing. Nanibala Ghosh's Aryabarta is published in 1933 by Shashibhushan Ghosh of Dhapdhapi (24 Parganas) and Messrs. Gurudas Chatterjee and Sons, Cornwallis Street, Calcutta. It is priced at Rupees Two, and the text is accompanied by reviews from contemporary luminaries, as well as newspapers such as the Amritabazar Patrika and Anandabazar Patrika, among others. The reviews praise the text as an upstanding work of travel literature, and several are quick to point out the scarcity of travel writing by women. A short critique of the text by one Sri Binaykumar Sarkar at the beginning of the book betrays the contemporary proclivity to prefer a clinical approach to travel writing. Sarkar's credibility is established as a "Renowned Professor and Litterateur", and he goes on to say the following about the work:

This book about travelling to Kashmir - 'Aryavarta' is an excellent specimen of Bengali literature. Srimati Nanibala Ghosh is a seasoned writer. In the book we find routes for travel and rivers, mountains, forests, and a drive to make friends with a varied group of men and women. Because of this, it is as though Kashmir's towns and neighbourhoods are floating before my eyes. [...] The writer isn't given to random expressions of thoughts and feelings. She has preferred instead to provide us with accurate details. Along with this has come to the fore some of her poetry that is sensitive. The people of Bengal will consider this text a gem among travel writing for many years to come. (Ghosh, 1933, p.6)

Through this short critique we see clear lines drawn between "literature"-an exclusive category that affords space for subjective observations-and travel writing. Moreover, we see mindfulness and concern about the legacy of travel writing as a genre.

Indeed, Nanibala's Aryabarta is a work of precision, comprising a detailed page of contents, 38 half tone photographs of the places visited, an itemised list of said photographs, and an appendix (Ghosh, 1933). The appendix alone is testament to the work's scientific disposition. It is subdivided into three sections to chart, respectively, the travel routes between Jammu and Srinagar, Rawalpindi and Srinagar, and Havelian Abbottabad and Srinagar. Nanibala includes the distance between stations in miles, the altitude from sea level in feet, and abbreviations for important stops for each station, with the key: $[\mathrm{P}]$ post office, $[\mathrm{T}]$ telegraph office, $[\mathrm{R}]$ rest house, [H] hotel, [Dh] dharmashala, [D] dak bungalow, [toll] toll gate, etc. Apart from this, at various points within the text she provides practical data about room rent and ticket price.

Most of the text follows a similar tone and propensity for detail. There are a total of four chapters. The first focuses primarily on housekeeping, logistics, and the departure. The second section begins with their journey to Taxila to see the ancient ruins, through Jawlian, MohraMoradu, and Sarkop. In the third section Nanibala and her husband visit Haruyan, Tanmarg, Gulmarg, and stay in a houseboat on Dal Lake before proceeding to Jammu. The final chapter focuses on their stay in Jammu and the journey home. Although the text is titled Aryabarta, it has little in common with the 1885 text by the same name which was authored by Prasannamae Debi. The former could well be considered a travel guide to Kashmir filled with historical and statistical data, and the latter a proto-nationalist work of travel.

W. J. T. Mitchell in his introduction to Landscape and Power (2002) talks of landscape as a mode of identity formation, as opposed to a visual entity. He suggests that the idea of landscape shifts from a passive visual medium (either as an art form or text) to an active one which possesses the ability to construct the identity of that which it represents. The meaning of the landscape and its representation, thus, becomes secondary to what the representation achieves. This theory can be applied to the travel writing which emerges out of Bengal during the turn of 
the century. Travel writing as a genre becomes the site where reactions to, and ruptures from colonial encounters play out to achieve specific ends. In the 1880's, at the start of Bengali nationalism, merely the geographical limits of a nation no longer sufficed to provide a united sense of national identity. The plurality of the colonised nation is sought to be reconciled within the imagined space of aryavarta. Fifty years later, with a firm evolution of nationalism in Bengal, and with the availability of other avenues such as the Swadeshi movement to channelise nationalistic fervour, the onus is no longer solely on the terrain of aryavarta to provide a mythic and glorious anchor to the nation's people. Instead, the writer of travel is free to engage with the more pragmatic aspects of journeys, and indeed produce texts with the aim of facilitating journeys for the people of the nation. One no longer needs to imagine the sacred land, one could simply follow the train routes provided in appendices to visit it. Thus, landscape and its affect become contingent upon their representation through travel literature, and travel writing as a genre emerges as a multifaceted tool to this end.

\section{References:}

Basu, Subarnaprabha. (1885). Taj Mahal. Rpt. (2016) In D. Dasgupta (Ed.), Amadiger Bhraman Brittanta I 1(pp. 103-105). Kolkata: Gangchil.

Bayly, C.A. (1999). Empire and Information: Intelligence Gathering and Social Communication in India,17801870. UK: Cambridge University Press.

Bidyalankar, M. (1838). Rajabali (4 ${ }^{\text {th }}$ ed.). Retrieved from https://archive.org/details/dli.bengal.10689.4686/mode/2up

Chatterjee, K. (1995). Nature, History \& Nationalism: The Travel Narratives of a South Asian Colonial Elite. American Journal of Semiotics 12(1), 381-402.

Chatterjee, P. (1993). The Nation and its Fragments. New Jersey: Princeton University Press.

Chattopadhyay, Bankimchandra. (1999). Banglar Itihas. In K. Basu (Ed.), Bankim Rachanabali, Vol II. (pp. 289-291). Kolkata: Reflect Publication.

Chattopadhyay, T. (1876). Bharatbarser Itihas I. Kolkata: Self-published.

Chunder, B. (1869). The Travels of a Hindoo to Various Parts of Bengal and Upper India Vol 1. London: N. Trubner \& Co. Retrieved from https://archive.org/details/in.ernet.dli.2015.100107.

Dasgupta, D. (Ed.) (2016 \& 2017.).Amadiger Bhraman Brittanta: Unabingsha Shatabdir Bangamahilader Bhramankatha I \& II. Kolkata: Gangchil.

Das, Krishnabhabini. (1885). Englande Bangamahila. Rpt. In D. Dasgupta (Ed.)Amadiger bhraman brittanta: unabingsha shatabdir bangamahilader bhramankatha II (pp.53-251). Kolkata: Gangchil.

Ghosh,N.(1933). Aryabarta. Calcutta: Kalika Press. Retrieved from https://archive.org/details/in.ernet.dli.2015.339261.

Girindranandini Debi (1897). Dholpur. Calcutta.

Jha, S. (2017, August 12). The Life and Times of Bharat Mata: Nationalism as Invented Religion. Manushi. Retrieved from http://manushi.in/docs/196-the-life-and-times-of-bharat-mata.pdf.

Mitchell, W. J. T. (2002). Landscape and Power. Chicago: University of Chicago Press.

Mukhopadhyay, B. (2002). Writing Home, Writing Travel: The Poetics and Politics of Dwelling in Bengali Modernity. In Comparative Studies in Society and History 44(2), 293-318. Doi: 10.1017/Soo10417502000142. 
Mukhopadhyay, S. (2018).Paradhin bharate paradhin nari: Bhramankathay swadesh o samajchetana. Kolkata: Gangchil.

"National Song", Wayback Machine, archived January 15, 2013, https://web.archive.org/web/20130115003651/http://knowindia.gov.in/knowindia/national_symbols.php ?id=12.

Nayar, P. K. (2005). Marvellous Excesses: English Travel Writing and India, 1608-1727. In Journal of British Studies 44(2),213-38.

Prasannamae Debi. (1885). Aryabarta: Jonoiko Bangla Mahilar Bhraman Brittanta. Rpt. (2017) In D. Dasgupta (Ed.) Amadiger Bhraman Brittanta: Unabingsha Shatabdir Bangamahilader Bhramankatha. II (pp.322-399). Kolkata: Gangchil.

Rassundari Dasi. (1876). Amar Jiban. Rpt. (2002).Calcutta: College Street Publication Pvt Ltd.

Sarkar, T. (2001). Aspects of Contemporary Hindutva Theology. In Hindu Wife, Hindu Nation. New Delhi: Permanent Black.

Schaffer, S. (1986). Scientific Discoveries and the End of Natural Philosophy. In Social Studies of Science, 16(3), 387-420.

Sen, S. (2005). Travels to Europe: Self and Other in Bengali Travel Narratives, 1870 - 1910. New Delhi: Orient Blackswan.

Shekhar, Divya. (2017, February 23). Date with History: The Mysore Dewan Who Led Cauvery act Team 93 Years Ago. The Economic Times. Retrieved from

http://epaperbeta.timesofindia.com/Article.aspx?eid=31815\&articlexml=Date-with-History-The-MysoreDewan-who-Led-23022017004036.

Swarnakumari Debi. (1888). Darjeeling Patra. Bharati. XII. Calcutta: Brahmo Samaj Press. Retrieved from http://crossasia-repository.ub.uni-heidelberg.de/389/.

Vivekananda, Swami. The Common Bases of Hinduism/ Lectures from Colombo to Almora. The Complete Works of Swami Vivekananda. 3. Wikisource. Last modified July 9, 2013. https://en.wikisource.org/wiki/The_Complete_Works_of_Swami_Vivekananda/Volume_3/Lectures_fro m_Colombo_to_Almora/The_Common_Bases_of_Hinduism.

Shrutakirti Dutta is a PhD scholar at the department of English, Jadavpur University, Kolkata, where she is currently working on indigenous craft traditions of Bengal. She is project fellow for AHRC-funded collaborative project "Famine Tales from India and Britain 1550-180o", between University of Exeter and School of Cultural Texts and Records, Jadavpur University. Her MPhil dissertation focused on women's travel writing in colonial Bengal. Her research interests include nineteenth century print culture, women's histories, travel narratives and material cultures. 